\title{
Update on endometritis therapy
}

\author{
Terttu Katila \\ University of Helsinki, Department of Production Animal Medicine
}

\begin{abstract}
Summary: The corner stones of equine endometritis therapy are still antimicrobials and support of uterine evacuation. Ecbolic hormones, oxytocin and prostaglandins, and uterine lavage are the most commonly used treatments to increase uterine contractility and thereby uterine clearance. Prostaglandins are more long-acting than oxytocin and are therefore recommended in lymphatic stasis. Only non-irritant watersoluble antibiotics can be infused into the uterus. When deciding the route of administration - local or systemic - pharmacokinetic properties of antibiotics have to be taken into consideration. Chelating agents are recommended to increase the effect of antibiotics particularly in biofilm producing organisms. First generation Tris-EDTA is safe and non-irritant in the equine uterus. Third generation Tricide ${ }^{\circledR}$ has been used in the treatment of equine endometritis in volumes $250-500 \mathrm{ml}$. The drug binds to bacteria within minutes resulting in cell death and accumulation of debris, and therefore the uterus should be lavaged within $12 \mathrm{~h}$ to remove these by-products. The use of mucolytics has increased and kerosene and DMSO have been replaced by N-acetylcysteine (NAC). NAC removes inspissated secretions, exudate and biofilm and possesses antioxidant, anti-inflammatory and antimicrobial properties. Intrauterine treatment is well tolerated, but a lavage 4-12 hours later is recommended. NAC-treatment has been shown to increase pregnancy rates in barren mares and in repeat breeders. Immunomodulators, corticosteroids and cell-wall extracts, are the recent additions to our toolkit. They seem to alter expression of cytokines in susceptible mares. Pregnancy rates are increased after a single dose of dexamethasone shortly before or at the time of mating in mares that accumulate intrauterine fluid during estrus. Platelet-rich-plasma is the newest therapeutic method but needs still more research. In experiments with a limited number of mares it was shown to down-regulate pro-inflammatory cytokines and inflammation and increase pregnancy rates in problem mares.
\end{abstract}

Keywords: endometritis / therapy /antibiotics / mucolytics / dexamethasone / prostaglandins / oxytocin / reproduction / horse

Citation: Katila T. (2016) Update on endometritis therapy. Pferdeheilkunde 32, 39-45

Correspondence: Terttu Katila, Professor, Department of Production Animal Medicine, Faculty of Veterinary Medicine, University of Helsinki, Paroninkuja 20,04920 Saarentaus, Finland, E-mail: terttu.katila@helsinki.fi

\section{Introduction}

The corner stones of equine endometritis therapy are still antimicrobials and support of uterine evacuation. Chelating agents are recommended to increase the effect of antibiotics particularly in biofilm producing organisms. The use of mucolytics has increased and kerosene and DMSO have been replaced by $\mathrm{N}$-acetylcysteine. Immunomodulators, corticosteroids and cell-wall extracts, are the recent additions to our toolkit. Platelet-rich-plasma is the newest therapeutic method but needs still more research.

\section{Platelet-rich plasma}

Platelet-rich plasma (PRP) is autologous blood plasma that has been enriched with platelets by centrifugation. It contains - and releases through degranulation - several different growth factors and cytokines that stimulate tissue repair. Although PRP is used in many indications in human medicine, large-scale controlled clinical trials are lacking.

Three abstracts have been published about the treatment of equine endometritis using PRP. Metcalf and Troedsson (2012) used 9 barren mares with a history of persistent mating induced endometritis (PMIE). The mares were inseminated and an endometrial biopsy was obtained the following day. All mares underwent an untreated cycle followed by a PRP-treated cycle. The mRNA expression of interleukins (IL) $1 \beta, 6$ and 8 and inducible nitric oxide synthase (iNOS) was significantly downregulated in the treated cycle as compared to the non-treated cycle. In the next experiment, Metcalf (2014) had 16 mares that had been barren for $>2$ years. The mares underwent a non-treated cycle and a cycle where $10 \mathrm{ml}$ of PRP was infused into the uterus before insemination (Al). Pregnancy rate in the treated cycle was significantly higher than in the non-treated cycle (67 vs 19\%) and accumulation of intraluminal fluid was significantly less (22 vs 100\%).

Reghini et al. (2014) inseminated 15 resistant and 8 susceptible mares in two cycles: treated and non-treated. In the treatment cycle, the mares received $20 \mathrm{ml}$ of PRP into the uterus $4 \mathrm{~h}$ after $\mathrm{Al}$. The resistant mares showed no differences between the cycles in $\mathrm{NO}$ concentration or in intrauterine (IU) fluid accumulation, but neutrophils in cytology diminished during the treated cycle. In susceptible mares, a significant decrease was observed after PRP treatment in the three parameters examined. All three experiments were conducted with a small number of mares, so no definite conclusions can be drawn. However, PRP might be worth trying to control PMIE in problem mares that do not seem to benefit from standard treatments.

\section{Immune modulators}

The breeding induced inflammation involves chemokine-initiated recruitment of neutrophils to the uterus leading to the removal of excess spermatozoa and pathogens. There is a delicate balance between pro- and anti-inflammatory cytokines. Susceptible mares appear to have altered expression of cytokines, particularly a deficit in the production of anti- 
inflammatory cytokines after mating (Woodward et al. 2013a). Immunomodulatory therapies have been designed to restore the cytokine balance in problem mares.

\section{Corticosteroids}

In a Brazilian study, prednisolone acetate $(0.1 \mathrm{mg} / \mathrm{kg})$ was administered every $12 \mathrm{~h}$ : four times before $\mathrm{Al}$ and the last one at Al. Pregnancy rates of 30 normal mares did not differ in the treated vs non-treated cycle, but significantly higher pregnancy rates were reported after prednisolone treatment in 15 barren mares with a history of fluid accumulation after post-ovulatory frozen semen $\mathrm{Al}$ as compared to the non-treated cycle (64.5\% vs $0.0 \%$ ) (Papa et al. 2008).

A single dose of dexamethasone $(50 \mathrm{mg}$ IV) immediately before breeding reduced the turbidity of the efflux, edema and fluid accumulation. In a field trial, 347 mares in 513 cycles were bred. Pregnancy rates in control and dexamethasone treated cycles were not significantly different unless the mares had $\geq 3$ risk factors of 4 of the following: $\geq 2 \mathrm{~cm}$ fluid prior to breeding or after breeding or persisting $>36 \mathrm{~h}$ or abnormal cervix (Bucca et al. 2008). The dexamethasone treatment has been shown to be safe and does not interfere with ovulation induction (Bucca and Carli 2011).

When dexamethasone $(0.1 \mathrm{mg} / \mathrm{kg}$ IV) was given to susceptible mares $24 \mathrm{~h}$ before IU E.coli infusion, the innate immune response was modulated. Expression of pro-inflammatory cytokines (IL-1 $\beta, I L-6, I L-8)$ and serum amyloid A (SAA) was significantly lower in the dexamethasone treated group at 72 $\mathrm{h}$ and increased expression of the anti-inflammatory cytokine IL-10 was observed at 3 and $24 \mathrm{~h}$ (Christofferson et al. 2012).

Dexamethasone administration (10 or $20 \mathrm{mg}$ ) after $\mathrm{Al}$ did not improve pregnancy rates (Vandaele et al. 2010); the injection has to be given prior to mating to be able to affect cytokine release. Dexamethasone administration shortly before or at mating is a safe and efficient method to modulate the immune response in selected problem mares.

\section{Non-steroid anti-inflammatory drugs}

Dexamethasone treatment may exacerbate bacterial endometritis and may contribute to laminitis. Therefore non-steroid inflammatory drugs (NSAID) have been tested in the inhibition of PMIE. Vedaprofen, an inhibitor of cyclooxygenase-2 (COX-2), was given orally, $1 \mathrm{mg} / \mathrm{kg}$ twice daily, from one day before $\mathrm{Al}$ to one day after ovulation to 8 barren mares with a history of repeated PMIE; 9 mares were left untreated (controls). In addition, the mares were given $20 \mathrm{IU}$ of oxytocin (OT) SC thrice daily. Although there were no differences in neutrophil numbers or in the accumulation of IU fluid, 2/9 mares conceived in the control group and 7/8 mares in the treatment group (Rojer and Aurich 2010).

Another NSAID, flunixin meglumine, decreased endometrial inflammation in biopsies obtained $8 \mathrm{~h}$ after $\mathrm{Al}$, but more neutrophils were present in uterine lavage fluid suggesting that the suppression of uterine clearance was more important than the initial inflammation (Risco et al. 2009). In the study of Rojer and Aurich (2010), the suppression of uterine contractions was overcome by the frequent OT administration. However, the protocol of twice daily oral administration of vedaprofen and thrice daily injections of OT during the insemination period requires a lot of work and may not be worth it.

\section{Bacterial cell-wall extracts}

Bacterial cell wall skeletons have the ability to stimulate immune system, including induction of cytokine synthesis by immune cells. Mycobacterium cell wall extract (MCWE) from Mycobacterium phlei is commercially available as SETTLETM (Bioniche Animal Health USA) in North-America and can be administered IV or IU with the dose of $1.5 \mathrm{mg}$ (Rogan et al. 2007). It seems to have better efficacy against streptococci than against E.coli (Rogan et al. 2007, Christofferson et al. 2012). In the study of Rogan et al. (2007), 30 susceptible mares were used; $55 \%$ of the treated mares had eliminated the streptococcal inoculation after $24 \mathrm{~h}$ and $75 \%$ by 7 days when all control mares were still positive. Associated with the enhanced bacterial elimination also neutrophils and IU fluid decreased significantly.

MCWE-treatment has been reported to decrease $\mathrm{NO}$ which was elevated in susceptible mares (Woodward et al. 2013b). Fumuso et al. (2007) showed increase of IL-10 and decrease of IL-1b $24 \mathrm{~h}$ after $\mathrm{Al}$ and MCWE-treatment in susceptible mares. On the other hand, Christoffersen et al. (2012) did not see any change in cytokines in an experiment where susceptible mares were treated with MCWE $24 \mathrm{~h}$ after $\mathrm{E}$. coli inoculation. However, MCWE treatment decreased significantly SAA. It can be concluded that MCWE has some immunomodulatory effect and may have potential in the treatment of streptococcal endometritis.

Another immunomodulator is Eqstim ${ }^{\circledR}$ (Neogen Corp., Lexingto, KY, USA) which contains Propionibacterium acnes. When Eqstim ${ }^{\circledR}$ was administered to mares with persistent endometritis, 1/12 mares had endometrial inflammation 10 days after inoculation, whereas 18/21 control mares were inflamed (Rohrbach et al. 2007). In a subsequent experiment, 95 mares with a positive cytology were treated IV with Eqstim ${ }^{\circledR}$ or placebo on days 0,2 and 6 and bred within 8 to 30 days after the treatment. Live foal rates were $73 \%$ for treated mares and $43 \%$ for controls. The optimal treatment effect was detected in mares bred during the time interval from 2 days before to 8 days after the first treatment (Rohrbach et al. 2007).

\section{Solvents and mucolytics}

Kerosene

In Australasia, IU infusion of kerosene has been used for decades to treat subfertile mares and good results have been reported. Bracher et al. (1991) studied uterine biopsies in 4 normal mares (biopsy category I) and in 24 subfertile mares (biopsy category II or III) before and after IU kerosene infusion $(50 \mathrm{ml})$. Kerosine induced a severe acute inflammation of 
short duration. In addition, necrosis of the luminal epithelium and glandular activation were observed. Foaling rates in the three biopsy categories were the same, but the initial conception rate was astonishingly high in the worst biopsy group III. The authors advocated the use of kerosene as a chemical curettage which would remove the superficial layer of the degenerative endometrium. However, it is not certain that the "new" tissue is any better. Bradecamp et al. (2014) studied ciliated endometrial epithelial cells after IU kerosene treatment. Kerosene decreased cilia significantly but at 21 days only the control group showed significant increase in the percentage of ciliated cells.

The presumed positive effect of kerosene is probably not related to its pro-inflammatory or curettage effect. Kerosene like distillates have been used to treat people since ancient times. It seems to kill fungi, particularly Candida. It is a solvent and therefore may remove excess mucus in mare endometrium. However, because of the strong inflammation and toxicity it cannot be recommended as a routine therapy.

\section{Dimethyl sulfoxide}

Dimethyl sulfoxide (DMSO) is a solvent that has been used since 1950s in various indications to treat humans and animals. It penetrates membranes very well and has antiinflammatory, analgesic, antibacterial and antifungal properties. No harmful histological changes were noted after IU DMSO infusion in mares as reported by Ley et al. (1989). Thirty percent IU DMSO therapy improved endometrial biopsy classification in 18 of 27 barren mares and tended to improve pregnancy rates (Ley et al. 1989). Because of the disgusting odor, possible allergic reactions and neurotoxicity and carcinogenicity in high doses it is not the preferred treatment.

\section{N-acetylcysteine}

$\mathrm{N}$-acetylcysteine (NAC) is a mucolytic agent that disrupts disulphide bonds between mucin polymers, thereby reducing the viscosity of mucus. In addition, NAC possesses antioxidant properties especially in chronic inflammatory conditions and some antimicrobial properties. The rational for using NAC uterine infusions in equine endometritis is the removal of inspissated secretions, exudate and biofilm (LeBlanc 2010). However, in an in vitro study (Ferris et al. 2014), NAC did not prevent biofilm biomass formation; it reduced the biofilm mass in P. aeruginosa, but not in E. coli or K. pneumonia isolates.

Oral NAC treatment does not reduce viscosity of uterine mucus but has an anti-inflammatory effect: less neutrophils and lower staining for COX-2 were demonstrated (Witte et al. 2012). Local treatment is well tolerated (Gores-Lindholm et al. 2009, LeBlanc 2010, Melkus et al. 2013) and therefore the preferred route of treatment is $I U$. Treatment of normal mares with $140 \mathrm{ml}$ of $5 \%$ NAC reduced inflammation: neutrophil numbers and intensity of staining for COX-2 were significantly lower at $72 \mathrm{~h}$ as compared to controls. Surprisingly, score for PAS (periodic acid-Schiff) staining in mucus was decreased only in deep uterine glands, not any other parts of the endometrium (Melkus et al. 2013). In the study of GoresLindholm et al. (2009), 3\% NAC inhibited the oxidative burst of serum-derived neutrophils and reduced extracellular mucus thickness and staining intensity.

Fertility trials look promising, although the number of mares has been limited. Twenty barren mares with a history of endometritis were treated with a $0.6 \%$ solution of NAC either during the cycle before or in the $48 \mathrm{~h}$ before breeding in addition to conventional treatments. The NAC-treatments were associated with a high pregnancy rate of $85 \%$ (GoresLindholm et al. 2009). In a subsequent study (Gores-Lindholm et al. 2013), 154 client-owned mares were assigned to one of the three breeding management groups: 1) 44 repeat breeders with mucus overproduction were treated with $3.3 \%$ NAC 24-36h before mating followed by OT 4 to $8 \mathrm{~h}$ later; 2) 85 reproductively normal mares; 3) 25 mares previously treated for endometritis. The first-cycle pregnancy rates for groups 1, 2 and 3 were $77 \%, 74 \%$ and $56 \%$, respectively, and early embryonic death rates were $15 \%, 13 \%$ and $7 \%$. It is unclear what kind of mucolytic effect NAC has in equine endometrium, but at least because of its antioxidant, antiinflammatory and antimicrobial properties it seems to improve the fertility of problem mares.

\section{Chelating agents}

Buffered chelating agent EDTA-Tris has been known long for its potentiating action of antimicrobials by increased drug penetration and for the ability to break up biofilm and dissolve exudate. In vitro, addition to gentamicin improved killing of $P$. aeruginosa by 1000-fold. Addition of EDTA-Tris to penicillin, oxytetracycline, neomycin, amikacin, miconazole and itraconazole is synergistic (LeBlanc 2010). It has been shown to be safe and non-irritant in the equine uterus (Youngquist et al. 1984).

First generation Tris-EDTA [ethylendiamine tetraacetic acid (3.5 M)-tromethamine $50 \mathrm{mM}$ ] and third generation Tricide ${ }^{\circledR}$ $(8 \mathrm{mM}$ disodium EDTA dehydrate and $20 \mathrm{mM}$ 2-amino2hydroxymethyl-1,2-propanediol; Medical Molecular Therapeutics LLC Georgia Biobusiness Center, Athens, Georgia) have been used in the treatment of endometritis mares (LeBlanc 2010).

Chelating agents have to come in direct contact with the bacterial cell wall to kill the organism so the volumes need to be large $(250-500 \mathrm{ml})$. The drug binds to the bacteria within minutes resulting in cell death and accumulation of debris, and therefore the uterus should be lavaged within $12 \mathrm{~h}$ to remove these by-products (LeBlanc 2010). LeBlanc (2010) recommended an additional treatment if the efflux is cloudy or has mucus strains; antibiotics can then be started on day 3 following uterine irrigation.

\section{Stimulation of uterine contractions}

Deficient uterine contractility is considered to be the main reason for delayed uterine clearance and susceptibility to endometritis (Troedsson et al. 1993, Troedsson 1999). That is why ecbolic hormones, oxytocin and prostaglandins, as well 
as uterine lavage, are the most common treatments of mares with a tendency to accumulate IU fluid during estrus, and particularly after mating.

\section{Uterine lavage}

Uterine lavage $12 \mathrm{~h}$ after $\mathrm{IU}$ inoculation of Streptococcus zooepidemicus reduced the growth of bacteria and the number of neutrophils (Troedsson et al. 1995b). Post-breeding uterine lavage is often used together with OT injections and this combination has been shown to work (Knutti et al. 2000).

Uterine irrigation improves physical clearance and removes inflammatory debris (LeBlanc and Causey 2009). Some antibiotics are inactivated by the presence of pus, so uterine lavage before local antibiotic infusion is indicated. Lactated Ringer's solution or physiological saline are used as irrigation fluids, sometimes supplemented with dilute povidone-iodine. Usually one liter is infused into the uterus and recovered. The procedure is repeated until clear efflux is obtained (LeBlanc and Causey 2009).

Uterine lavage is commonly practiced in mares with IU fluid during estrus. Excess uterine fluid adversely affects sperm motility and therefore removal of fluid is indicated. Mares can be flushed only one hour before breeding when lactated Ringer's is used (Vanderwall and Woods 2003). After breeding, uterine lavage can be conducted as early as $4 \mathrm{~h}$ post-mating without deleterious effects on pregnancy rates (Brinsko et al.1991). It is best to let the early inflammatory response to take its normal course and not to interfere during the first hours after mating.

Healthy mares should not be lavaged when there is no reason. Mucus plays an important role in protecting and cleansing of mucosal surfaces. Fluid in the uterus can disrupt mucociliary function and ciliary currents. Hydration of the mucus alters its elasticity and viscosity and thereby compromises adequate function (LeBlanc and Causey 2009). Removal of "good" mucus does no good to the mare.

\section{Oxytocin}

Although it has been known for decades that OT stimulates uterine contractions, it had not been used in association with mating until Allen reported about its use in mares with IU fluid in 1991. It had been suspected that exogenous OT around the time of ovulation could adversely influence the transport and function of gametes (Allen 1991). LeBlanc et al. (1994) showed how OT enhanced uterine clearance both in normal and in infertile mares. Since that many studies have reported the beneficial effect of OT treatment post-mating on removal of IU fluid accumulations and on pregnancy rates (Pycock 1994, Pycock and Newcombe 1996, Rasch et al. 1996, Knutti et al. 2000). Risco et al. (2009) showed that not only does OT effectively and rapidly remove fluid after Al but by doing so it also shortens the duration of post-breeding inflammation.

The only drawback of OT is the short half-life $(7 \mathrm{~min})$ (Paccamonti et al. 1999) and subsequently short duration of the contractile effect. The duration of effect is dose-dependent varying from $10 \mathrm{~min}(2 \mathrm{IU})$ to $99 \mathrm{~min}(40 \mathrm{IU})$ (Cadario et al. 1999, Madill et al. 2002). However, a high dose given IV may result in uterine spasm instead of contractions (Campbell and England 2002). Although IV OT doses of 2.5, 5, 10, and $20 \mathrm{IU}$ increased uterine contractions numerically, only $5 \mathrm{IU}$ resulted in significantly higher uterine clearance and the dose of $30 \mathrm{IU}$ decreased contractions because of a sustained contraction (Campbell and England 2002). Risco et al. (2009) reported a good effect of OT after Al using only $0.01 \mathrm{IU} / \mathrm{kg}$ IV. In the study of Rasch et al. (1996), 15 IU of OT resulted in higher pregnancy rates than $25 \mathrm{IU}(78 \%$ vs $52 \%$, respectively). It can be concluded that the IV doses of OT between 5 and $15 \mathrm{IU}$ give optimal contractility and the dose of $20 \mathrm{IU}$ should not be exceeded.

A long-acting synthetic OT analogue, carbetocin has a halflife of $17 \mathrm{~min}, 2.5$ times that of OT. Carbetocin was well tolerated in horses following IV administration of $175 \mu \mathrm{g}$ and can be useful in mares which need more prolonged uterine contractions (Schramme et al. 2008).

\section{Prostaglandins}

If the mare does not respond to OT, prostaglandins (PG) are another alternative. PGF2 administration $12 \mathrm{~h}$ after IU inoculation of Str. zooepidemicus reduced the growth of streprococci and the number of neutrophils (Troedsson et al. $1995 \mathrm{~b})$. However, administration of PG $>12 \mathrm{~h}$ after ovulation decreases progesterone concentrations and if given 2 days after ovulation may decrease pregnancy rates (LeBlanc and Causey 2009).

In equine practice, PGF2 and its analogues fenprostalene and cloprostenol are commonly used. Cloprostenol appears to be the most consistent in the stimulation of uterine contractility and clearance (Combs et al. 1996).

The action of PG starts within 8 to 10 min after an IM injection. The duration of the effect is dose dependent and has been reported to vary from $40 \mathrm{~min}(2.5 \mathrm{mg}$ of PGF2 ) to $5 \mathrm{~h}$ (10 mg of PGF2) (Goddard and Allen 1985, Troedsson et al. 1995a).

Uterine contractions are weaker but more prolonged after administration of PG than after OT. For this reason, PGs have been advocated for mares with lymphatic stasis because lymphatic drainage requires sustained uterine contraction. The recommended treatment for lymph stasis is uterine irrigation 4 to $8 \mathrm{~h}$ after mating to remove inflammatory by-products. Immediately after lavage, 5 to $20 \mathrm{IU}$ of OT is given IV to produce rapid clearance of uterine contents. Cloprostenol given after that produces low-amplitude contractions that persist for 4-5h assisting in lymph flow (LeBlanc and Causey 2009).

\section{Antimicrobials}

The arsenal of antibiotics suitable for the local treatment of endometritis is limited in EU. New antibiotics have not been launched lately in veterinary medicine. More antibiotics are available for systemic use, but the pharmacokinetic properties 
are not always suited for uterine infections. In general, high lipid solubility, low protein binding and a high degree of nonionization favor distribution throughout the body (Pyörälä et al. 2014).

Anything that we put into into the uterus has to be non-irritant and water soluble. This excludes e.g., enrofloxacin, tetracyclines, and trimethoprim-sulfonamide combinations. Fortunately enrofloxacin and trimethoprim have a large volume of distribution and produce high concentrations also in peripheral parts of the body including the uterus and are thus efficacious also in systemic use. Tetracyclines have moderate lipidsolubility and can yield therapeutic concentrations in reproductive organs. However, because of their side-effects tetracyclines are not commonly used in horses (Pyörälä et al. 2014). In a Swedish study, enrofloxacin was the only of 10 tested antibiotics for which no $\mathrm{E}$. coli isolate was resistant but $15 \%$ of $E$. coli isolates were resistant to trimethoprim/sulphamethoxazole, $22 \%$ to streptomycin, $11 \%$ to ampicillin and $4 \%$ to gentamicin (Albihn et al. 2003). Similar sensitivity results were published from Florida: E. coli was most resistant to trimethoprim-sulfonamide and ampicillin and least to amikacin and enrofloxacin (Davis et al. 2013).

Aminoglycosides, gentamicin and amikacin, have a very low $\mathrm{pH}$ and have to be buffered with an equal volume of $7.5 \%$ sodium bicarbonate in IU use. Their penetration into cells and tissues is generally poor via systemic route (Hagget and Wilson 2008), but gentamicin has been shown to be transferred to the placenta (Pyörälä et al. 2014). Aminoglycocide activity is predominantly limited to aerobic Gram-negative bacteria and they have good activity also against Pseudomonas spp. (Hagget and Wilson 2008).

Ceftiofur is a 3rd generation cephalosporin which should be used only in selected cases; in Finland it is registered only for foals (Pyörälä et al. 2014). It is more effective locally than systemically but penetrates to some extent body fluids.

Sodium or potassium salts of penicillin G IU are the drug of choice against streptococci, since at least in Scandinavia all streptococcal isolates from the equine endometrium were sensitive for penicillin (Albihn et al. 2003). Procain penicillin is mostly ionized in plasma and the distribution is limited, but against bacterial species with very low minimum inhibitory concentrations it can be tried IM (Pyörälä et al. 2014).

Carboxypenicillins, ticarcillin and carbenicillin, are mostly used against Pseudomonas. Ticarcillin combined with clavulanic acid (a $\beta$-lactamase inhibitor) has a broad spectrum covering both Gram-negative and -positive organisms. Carbenicillin has to be buffered before IU administration.

Fungal endometritis needs a long treatment, often longer than the estrus length. Therefore the initial local treatment with antimicrobials can be continued with per oral administration of ketoconazole, itraconazole or fluconazole for two to three weeks. Susceptibility patterns of fungal isolates from equine endometrium in Cornell were the following: nystatin $100 \%$, natamycin 100\%, amphotericin B 96\%, ketoconazole $81 \%$, clotrimazole $80 \%$, itraconazole $61 \%$, fluconazole $44 \%$ and miconazole $44 \%$ (Coutinho da Silva and Alvarenga $2011)$.

\section{References}

Albihn A., Båverud V., Magnusson U. (2003) Uterine microbiology and antimicrobial susceptibility in isolated bacteria from mares with fertility problems. Acta vet. scand. 44, 121-129

Allen W. E. (1991) Investigations into the use of exogenous oxytocin for promoting uterine drainage in mares susceptible to endometritis. Vet. Rec. 128, 593-594

Bracher V., Neuschaefer A., Allen W. R. (1991) The effect of intrauterine infusion of kerosene on the endometrium of mares. J. Reprod. Fert. (Suppl. 44), 706-707

Bradecamp E. A., Ahlschwede S. A., Cook J. L. (2014) The effects of intra-uterine kerosene infusion on endometrial epithelial cilia concentration. J. Equine Vet. Sci. 34, 134

Brinsko S. P., Varner D. D., Blanchard T. L. (1991) The effect of uterine lavage performed four hours post insemination on pregnancy rate in mares. Theriogenology $35,1111-1119$

Bucca S., Carli A. (2011) Efficacy of human chorionic gonadotropin to induce ovulation in the mare, when associated with a single dose of dexamethasone administered at breeding time. Equine Vet. J. (Suppl.) 40, 32-34

Bucca S., Carli A., Buckley T., Dolci G., Fogarty U. (2008) The use of dexamethasone administered to mares at breeding time in the modulation of persistent mating induced endometritis. Theriogenology 70, 1093-1 100

Cadario M. E., Merritt A. M., Archbald L. F., Thatcher W. W., LeBlanc M. M. (1999) Changes in intrauterine pressure after oxytocin administration in reproductively normal mares and in those with a delay in uterine clearance. Theriogenology 51, 1017-1025

Campbell M. L. H., England G. C. W. (2002) A comparison of the ecbolic efficacy of intravenous and intrauterine oxytocin treatments. Theriogenology 58, 473-747

Christoffersen M., Woodward E. M., Bojesen A. M., Petersen M. R., Squires E. L., Lehn-Jensen H., Troedsson M. H. T. (2012) Effect of immunomodulatory therapy on the endometrial inflammatory response to induced infectious endometritis in susceptible mares. Theriogenology 78, 991-1004

Combs G. B., LeBlanc M. M., Neuwirth L., Tran T. Q. (1996) Effects of prostaglandin F2alpha, cloprostenol and fenprostalene on uterine clearance of radiocolloid in the mare. Theriogenology 45 , 1449-1455

Coutinho da Silva M. A., Alvarenga M. A. (201 1). Fungal endometritis. In: Equine Reproduction, vol. 22nd ed., eds McKinnon A. O., Squires E. L., Vaala W. E., Varner D. D., Wiley-Blackwell, pp. 2643-2651

Davis H. A., Stanton M. B., Thungrat K., Boothe D. M. (2013) Uterine bacterial isolates from mares and their resistance to antimicrobials: 8,296 cases (2003-2008). J. Am. Vet. Med. Assoc. 242, 977-983

Ferris R. A., Wittstock S. M., McCue P. M., Borlee B. R. (2014) Evaluation of biofilms in gram-negative bacteria isolated from the equine uterus. J. Equine Vet. Sci. 34, 121

Fumuso E. A., Aguilar J., Giguére S., Rivulgo M., Wade J., Rogan D. (2007) Immune parameters in mares resistant and susceptible to persistent post-breeding endometritis: Effects of immunomodulation. Vet. Imm. Immunopath. 118, 30-39

Goddard P. J., Allen W. E. (1985) Genital tract pressures in mares. II. Changes induced by oxytocin and prostaglandin F2 . Theriogenology 24, 35-44

Gores-Lindholm A., Causey R., Calderwood-Mays M., LeBlanc M. M. (2009) Effect of intra-uterine infusion of diluted N-acetylcysteine on equine endometrium. Proc. Ann. Conv. Am. Ass. Equine Practitioners 55, 326

Gores-Lindholm A., LeBlanc M. M., Causey R., Hitchborn A., FayrerHosken A., Kruger M., Vandenplas M. L., Flores P., Ahlschwede S. (2013) Relationships between intrauterine infusion of $\mathrm{N}$-acetylcysteine, equine endometrial pathology, neutrophil function, postbreeding therapy, and reproductive performance. Theriogenology 80, 218-227

Haggett E. F., Wilson W. D. (2008) Overview of the use of antimicrobials for the treatment of bacterial infections in horses. Equine vet. Educ. 20, 433-448 
Knutti B., Pycock J. F., van der Weijden G. C., Küpfer U. (2000) The influence of early postbreeding uterine lavage on pregnancy rate in mares with intrauterine fluid accumulations after breeding. Equine vet. Educ. 12, 267-270

LeBlanc M. M. (2010) Advances in the diagnosis and treatment of chronic infectious and post-mating-induced endometritis in the mare. Reprod. Dom. Anim. (Suppl. 10) 45, $21-27$

LeBlanc M. M., Causey R. C. (2009) Clinical and subclinical endometritis in the mare: both threats to fertility. Reprod. Dom. Anim. (Suppl. 3) 44, 10-23

LeBlanc M. M., Neuwirth L., Mauragis D., Klapstein E., Tran T. (1994) Oxytocin enhances clearance of radiocolloid from the uterine lumen of reproductively normal and infertile mares. Equine vet. J. 26, 279-282

Ley W. B., Bowen J. M., Sponenberg D. P., Lessard P. N. (1989) Dimethyl sulfoxide intrauterine therapy in the mare: Effects upon endometrial histological features and biopsy classification. Theriogenology 32, 263-276

Madill S., Troedsson M. H. T., Santschi E. M., Malone E. D. (2002) Dose-response effect of intramuscular oxytocin treatment on myometrial contraction of reproductively normal mares during estrus. Theriogenology 58, 479-481

Melkus E., Witte T., Heuwieser W., Aurich C. (2013) Investigations on the endometrial response to intrauterine administration of $\mathrm{N}$-acetylcysteine in oestrous mares. Reprod. Dom. Anim. 48, 591-597

Metcalf E. S., Troedsson M. H. T. (2012) The effect of platelet-rich plasma (PRP) on endometrial proinflammatory cytokines in susceptible mares following semen deposition. J. Equine Vet. Sci. 32, 498

Metcalf E. S. (2014 The effect of platelet-rich plasma (PRP) on intraluminal fluid and pregnancy rates in mares susceptible to persistent mating-induced endometritis (PMIE). J. Equine Vet. Sci. 4, 128

Paccamonti D. L., Pycock J. F., Taverne M. A. M., Bevers M., van der Weijden G. C., Gutjahr S., Schams D., Blouin D. (1999) PGFM response to exogenous oxytocin and determination of the half-life of oxyłocin in non-pregnant mares. Equine vet. J. 31, 285-288

Papa F. O., Dell'Aqua Jr. J. A., Alvarenga M. A., Melo C. M., Zahn F. S., Lopes M. D. (2008) Use of corticosteroid therapy on the modulation of uterine inflammatory response in mares after artificial insemination with frozen semen. Pferdeheilkunde 24, 79-82

Pycock J. F. (1994) A new approach to treatment of endometritis. Equine vet. Educ. 6, 36-38

Pycock J. F., Newcombe J. R. (1996) Assessment of the effect of three treatments to remove intrauterine fluid on pregnancy rate in the mare. Vet. Rec. 138, 320-332

Pyörälä S., Taponen J., Katila T. (2014) Use of antimicrobials in the treatment of reproductive diseases in cattle and horses. Reprod. Dom. Anim. 49 (Suppl. 3), 16-26

Rasch K., Schoon H. A., Sieme H., Klug E. (1996) Histomorphologi$\mathrm{cal}$ endometrial status and influence of oxytocin on the uterine drainage and pregnancy rate in mares. Equine Vet. J. 28, 455460

Reghini M. F. S., Bussiere M.C. C., Ramires Neto C., Castro-Cheves M. M. B., Resende H. L., Fioratti E., Farras M. C., Alvarenga M. A. (2014) Effect of use of platelet rich plasma on post-breeding uterine inflammatory response of mares. J. Equine Vet. Sci. 34,127

Risco A. M., Reilas T., Muilu L., Kareskoski M., Katila T. (2009) Effect of oxytocin and flunixin meglumine on uterine response to insemination in mares. Theriogenology 72, 1195-201

Rogan D., Fumuso E., Rodriguez E., Wade J., Sánchez Bruni S. F. (2007) Use of mycobacterial cell wall extract (MCWE) in susceptible mares following semen deposition. Equine Vet. Sci. 32, 498

Rohrbach B. W., Sheerin P. C., Cantrell C. K., Matthews P. M., Steiner J. V., Dodds L. E. (2007) Effect of adjunctive treatment with intravenously administered Propionibacterium acnes on reproductive performance in mares with persistent endometritis. J. Am. Vet. Med. Assoc. 231, 107-113

Rojer H., Aurich C. (2010) Treatment of persistent mating-induced endometritis in mares with the non-steroid anti-inflammatory drug vedaprofen. Reprod. Dom. Anim. 45, e458-e460
Schramme A. R., Pinto C. R., Davis J., Whisnant C. S., Whitacre M. $D$. (2008) Pharmacokinetics of carbetocin, a long-acting oxytocin analogue, following intravenous administration in horses. Equine Vet. J. 40, 658-661

Troedsson M. H. T. (1999) Uterine clearance and resistance to persistent endometritis in the mare. Theriogenology 52, $461-471$

Troedsson M. H., Liu I. K., Ing M., Pascoe J., Thurmond M. (1993) Multiple site electromyography recordings of uterine activity following an intrauterine bacterial challenge in mares susceptible and resistant to chronic uterine infections. J. Reprod. Fert. 99, 307313

Troedsson M. H., Liu I. K., Ing M., Pascoe J. (1995a) Smooth muscle electrical activity in the oviduct and the effect of oxytocin, prostaglandin F2 and prostaglandin E2 on the myometrium and the oviduct of the cycling mare. Biol. Reprod. Mono 1, 475-488

Troedsson M. H., Scott M. A., Liu I. K. (1995b) Comparative treatment of mares susceptible to chronic uterine infection. Am. J. Vet. Res. 56, 468-472

Vandaele H., Daels P, Piepers S., LeBlanc M. (2010) Effect of postinsemination dexamethasone treatment on pregnancy rates in mares. Anim. Reprod. Sci. 121S, S110-S112

Vanderwall D. K., Woods G. L. (2003) Effect of fertility of uterine lavage performed immediately prior to insemination in mares. J. Am. Vet. Med. Assoc. 222, 1108-1110

Witte T. S., Melkus E., Walter I., Senge B., Schwab S., Aurich C., Heuwieser W. (2012) Effects of oral treatment with $\mathrm{N}$-acetylcysteine on the viscosity of intrauterine mucus and endometrial function in estrous mares. Theriogenology 78, 1199-1208

Woodward E. M., Christoffersen M., Campos J., Betancourt A. Horohov D., Scoggin K. E., Squires E. L., Troedsson M. H. T. (2013a) Endometrial inflammatory markers of the early immune response in mares susceptible or resistant to persistent breedinginduced endometritis. Reproduction 145, 289-226

Woodward E. M., Christoffersen M., Campos J., Horohov D., Scoggin K. E., Squires E. L., Troedsson M. H. T. (2013b) An investigation of uterine nitric oxide production in mares susceptible and resistant to persistent breeding-induced endometritis and the effects of immunomodulation. Reprod Dom Anim. 48, 554-561

Youngquist R. S., Blanchard T. L., Lapin D., Klein W. (1984) The effects of EDTA-Tris infusion on the equine endometrium. Theriogenology 22, 593-599

Erweiterte Zusammenfassung

\section{Die Therapie der Endometritis - ein Update}

Antibiotika sind für die Behandlung einer infektiösen Endometritis erforderlich, nicht jedoch bei Entzündungen nach einer Bedeckung. Die Auswahl von Antibiotika, die sich zur lokalen Behandlung von Endometritis eignen, ist in EU begrenzt. Neve Antibiotika wurden in letzter Zeit in der Tiermedizin nicht eingeführt. Es stehen mehr Antibiotika zur systemischen Anwendung zur Verfügung, aber ihre pharmakokinetischen Eigenschaften sind nicht immer für Gebärmutterinfektionen geeignet. In der Regel gegünstigen eine hohe Lipidlöslichkeit, eine geringe Proteinbindung und ein geringer Grad an lonenbildung die Verteilung im ganzen Körper. Alles, was wir in die Gebärmutter eingeben, darf nicht reizend und muss wasserlöslich sein. Dies schließt z.B. Enrofloxacin, Tetracycline und Trimethoprim-Sulfonamid-Kombinationen aus. Glücklicherweise haben Enrofloxacin und Trimethoprim ein großes Verteilungsvolumen und erzeugen hohe Konzentrationen auch in peripheren Teilen des Körpers einschließlich des Uterus und sind somit wirksam auch bei systemischer Anwendung. Tetracycline haben eine moderate Lipidlöslichkeit und therapeutische Konzentrationen in den Fortpflanzungsorga- 
nen können erreicht werden. Jedoch werden Tetracycline aufgrund ihrer Nebenwirkungen im Allgemeinen bei Pferden nicht eingesetzt. Es ist nachgewiesen, dass Isolate von E. coli aus equinen Endometritiden, am sensibelsten gegenüber Enrofloxacin und Amikacin reagieren und die höchste Resistenzrate gegenüber Trimethoprimsulfonamiden, Streptomycin und Ampicillin zeigen. Aminoglykoside, Gentamicin und Amikacin haben einen sehr niedrigen $\mathrm{pH}$-Wert und müssen zur intrauterinen Verwendung mit einem gleichen Volumen von 7,5\% Natriumbicarbonat gepuffert werden. Sie sind wirksam gegen Gram-negative Bakterien, einschließlich Pseudomonas spp. Natrium- oder Kaliumsalze von Penicillin G IU sind das Mittel der Wahl gegen Streptokokken. Procain-Penicillin wird meist im Plasma ionisiert und die Verteilung ist begrenzt, aber gegen Bakterienarten mit sehr niedrigen Hemmkonzentrationen kann es intramuskulär verabreicht werden. Durch Pilze bedingte Endometritiden erfordern eine lange Behandlung, oft über die Länge der Rosse hinaus. Daher wird die initiale antimykotische lokale Behandlung mit einer per os Verabreichung von Ketoconazol, Itraconazol oder Fluconazol für zwei bis drei Wochen fortgesetzt.

Eine mangelhafte Uteruskontraktilität gilt als der Hauptgrund für die Verzögerung der uterinen Clearance und die Anfälligkeit für eine Endometritis. Deshalb sind ekbolische Hormone, Oxytocin und Prostaglandine, sowie eine Uterusspülung die häufigsten Behandlungen bei Stuten mit einer Flüssigkeitsansammlung im Östrus, insbesondere nach der Bedeckung. Gebärmutterirrigationen verbessern die physische Clearance und Detritus wird entfernt. Einige Antibiotika sind bei Anwesenheit von Eiter unwirksam, daher ist eine Uteruslavage vor der lokalen Infusion mit Antibiotika indiziert. Ringer-Laktat- oder physiologische Kochsalzlösung werden als Spülflüssigkeiten eingesetzt, manchmal ergänzt durch verdünntes PVP-Jod. Üblicherweise wird ein Liter in den Uterus infundiert und rückgewonnen. Das Verfahren wird wiederholt, bis man eine klare Flüssigkeit gewinnt. Über die vorteilhafte Wirkung von Oxytocin zur Behandlung von Flüssigkeitsansammlungen nach Bedeckung und zur Erhöhung der Trächtigkeitsrate wurde in vielen Studien berichtet. Oxytocin ist nicht nur effektiv um Flüssigkeitsansammlungen nach Al schnell zu entfernen, es verringert gleichzeitig die Daver der Entzündung. Der einzige Nachteil ist die kurze Halbwertszeit (7 min) und die anschließende kurze Daver des Effektes auf die Kontraktion. Die Daver der Wirkung ist dosisabhängig, aber eine hohe intravenöse Dosis kann zu Gebärmutterspasmen anstatt zu Kontraktionen führen. Intravenöse Oxytocindosen zwischen 5 und $15 \mathrm{IU}$ erzeugen eine optimale Kontraktilität und die Dosis von $20 \mathrm{IE}$ sollte nicht überschritten werden. Wenn die Stute nicht auf Oxytocin reagiert, sind Prostaglandine (PG) eine weitere Alternative. Jedoch führt eine PG-Applikation mehr als $12 \mathrm{~h}$ nach dem Eisprung zu einer Abnahme der Progesteronkonzentration. PG-Gaben 2 Tage nach Ovulation führen zu einer Veminderung der Trächtigkeitsrate. In der Pferdepraxis werden PGF2 $\alpha$ und seine Analoga Fenprostalen und Cloprostenol häufig verwendet. Cloprostenol scheint am konsequentesten zur Stimulation der Uteruskontraktilität und zur Clearance zu führen. Die Wirkung von PG setzt innerhalb von 8 bis 10 min nach einer intramuskulären Injektion ein. Die Daver der Wirkung is dosisabhängig und bewegt sich zwischen 40 min und $5 \mathrm{~h}$. Die Uteruskontraktionen sind nach PG-Verabreichung schwächer, halten aber länger an als nach Oxytocingaben. Aus diesem Grund wird dem Prostaglandin bei Stuten mit lymphatischer
Stase der Vorzug gegeben, weil die Lymphdrainage eine nachhaltige Uteruskontraktilität erfordert.

Chelatbildner werden empfohlen, um die Wirkung von Antibiotika insbesondere bei Biofilm produzierenden Mikroorganismen erhöhen. Die erste Generation, das Tris-EDTA, ist sicher und nicht reizend in der equinen Gebärmutter. Die dritte Generation Tricide ${ }^{\circledR}$ wurde bei der Behandlung von equinen Endometritiden in Volumen von 250 bis $500 \mathrm{ml}$ verwendet. Der Wirkstoff bindet an den Bakterien innerhalb von Minuten, resultiert in deren Zelltod und zur Ansammlung von Detritus. Eine Uteruslavage sollte innerhalb von $12 \mathrm{~h}$ folgen, um diese Nebenprodukte zu entfernen.

Der Einsatz von Mukolytika hat zugenommen, wobei Kerosin und DMSO durch N-Acetylcystein (NAC) ersetzt wurden. NAC entfernt eingedickte Sekrete, Exsudate und Biofilme und besitz† antioxidative, entzündungshemmende und antimikrobielle Eigenschaften. Intrauterine Behandlungen werden gut vertragen, aber es wird eine Lavage 4-12 Stunden später empfohlen. Es hat sich gezeigt, dass eine NAC-Behandlung die Trächtigkeitsraten bei güsten Stuten und bei Umrossen steigert.

Immunmodulatoren, Kortikosteroide (Prednisolon und Dexamethason) und bakterielle Zellwandextrakte sind die jüngsten Ergänzungen unseres Toolkits. Es hat sich gezeigt, dass sie die Expression von Zytokinen bei empfänglichen Stuten verändern. Eine einzelne Dosis von Dexamethason unmittelbar vor der Bedeckung reduziert die Eintrübung des Effluxes, Ödeme und Flüssigkeitsansammlungen. In einem Feldversuch, waren die Trächtigkeitsraten bei der Kontrollgruppe im Vergleich zu Dexamethason behandelten Stuten nicht signifikant unterschiedlich. Dies galt nicht bei Stuten, die 3 oder mehr Risikofaktoren der folgenden 4 Faktoren aufwiesen: $\geq 2 \mathrm{~cm}$ Flüssigkeit vor oder nach der Bedeckung, persistierende Flüssigkeitsansammlung über $36 \mathrm{~h}$ oder eine abnormale Zervix. Eine Verabreichung von Dexamethason nach $\mathrm{Al}$ verbesserte nicht die Trächtigkeitsraten; die Injektion muss vor der Bedeckung erfolgen, um eine Zytokinfreisetzung zu bewirken. Dexamethason kurz vor oder zur Zeit der Bedeckung ist eine sichere und effiziente Methode, um die Immunantwort bei ausgewählten Problemstuten zu modulieren. Ein Zellwandextrakt aus Mycobacterium phlei ist im Handel als SETTLE ${ }^{\circledR}$ erhältlich. Es kann intravenös oder intrauterin verabreicht werden und scheint eine bessere Wirksamkeit gegen Streptokokken als gegen E.coli zu haben. Verbunden mit einer gesteigerten Beseitigung von Bakterien wird die Anzahl neutrophiler Granulozyten und das Volumen intraluminaler Flüssigkeit signifikant vermindert. Ein weiterer Immunmodulator ist Eqstim ${ }^{\circledR}$, das Propionibacterium acnes enthält. Ein optimaler Behandlungserfolg wird bei Stuten erreicht, die im Zeitintervall von 2 Tagen vor bis 8 Tage nach der ersten Behandlung bedeckt werden.

Plättchenreiches Plasma ist die neveste Behandlungsmethode, die jedoch noch weiter erforscht werden muss. In Experimenten mit einer begrenzten Anzahl von Stuten wurde gezeigt, dass eine Downregulation proinflammatorischer Zytokine und der Entzündung die Trächtigkeitsraten bei Problemstuten erhöht.

Schlüsselwörter: Pferd / Endometritis / Reproduktion / Therapie / Antibiotika / Mukolytika / Dexamethason / Prostaglandine / Oxitocin 